\title{
THE DIFFERENCES IN INDONESIAN ESL STUDENTS' MOTIVATION AND PERCEPTIONS OF NEST AND NNEST
}

\author{
Reza Anggriyashati Adara \\ Universitas Islam 45 Bekasi \\ reza@englit45bekasi.org
}

\begin{abstract}
Different teachers might have different influence on students' motivation as well as perceptions. The present study aims to analyze the differences in students' motivation and perceptions toward of two different types of teachers; NEST (Native English Speaking Teachers) and NNEST (Non-Native English Speaking Teachers). The present study applied a mixed method approach by distributing a set of questionnaires to sixty junior high school students and interviewing four of them to answer its research questions. The results indicate students' motivation to learn English with NEST because students think it will improve their speaking skills. In addition, NEST' accents and cultural knowledge motivate students to learn English with them. On the other hand, the results suggest that students are motivated to learn English with NNEST because they are more understanding to students' learning difficulties and NNEST can resort to students' L1 when students need it. Thus, students seem to have their own perceptions of the disadvantages and advantages of NEST and NNEST. To minimize the disadvantages, co-teaching seems imperative to be conducted to improve students' learning experience. In addition, pre-service teachers need to be aware of their own advantages and disadvantages either as NNEST or NEST. Educational institutions should also provide in-service teachers training to help their teachers reducing their disadvantages and maximizing their advantages
\end{abstract}

Keywords: students' motivations, students' perceptions, NEST, NNEST

\section{INTRODUCTION}

Despite the elusive nature of students' motivation (Dörnyei, 2001), it is a concept which is still highly investigated in FL (foreign language) learning (Dörnyei, 2005; Oxford and Shearin, 1994; Pae, 2017). In this regard, motivation can be defined as a combination of learners' efforts, desires, and attitudes to achieve the goal of language learning (Dörnyei and Ottó, 1998; Gardner, 2005; Loewen and Reinders, 2011). Some factors might be attributed to the importance of motivation in FL learning. Firstly, it is considered as a main drive which initiates FL learning (Dörnyei, 1998; Huang, 2007). Secondly, investigating motivation may provide educators as well as researchers with insights to sustain students' interest in FL learning (Dörnyei, 2005; Gardner, 1985). Thus, students' motivation can be considered as one of the most important aspects which influence success in second language acquisition (Carrió-Pastor and Mestre, 2014; McDonough, 1983). It can be said that without motivation, even the most dedicated learners might not be able to achieve long term goals of FL learning 
(Dörnyei and Csizér, 1998). The weight of evidence suggests the interest in researching motivation is attributed to its importance in FL learning.

One of important factors which influence students' motivation toward FL learning is teachers. Lamb (2007) indicated this point on his study on motivation of a group of junior high school students in rural area of Indonesia. Other studies also suggest teachers as factors that motivate students to learn English (Mesbah and Khazaie, 2014; Poornima et al (2016). Furthermore, Harmer (1991) argued that teachers can affect students' motivation as well as demotivation. The weight of evidence suggests that teachers are influential factors which affect students' motivation in FL learning. However, what kinds of teachers motivate students? In regards of present study, the aforementioned question is specifically addressed to two types of teachers; NEST (Native English Speaking Teachers) and NNEST (Non-Native English Speaking Teachers).

The superiority of NEST (Native English Speaking Teachers) over NNEST (Non-Native English Speaking Teachers) has sparked a debate as well as extensive research toward it (Albakrawi, 2014; Aslan and Thompson, 2016; Pae, 2017; Walkinshaw and Oanh, 2014; Wu and Ke, 2009). While non-native speakers can be defined as "speakers of language that is not their L1" (Boecher, 2005 , p. 68) or ones with limited access to the language or have few attributes of native speakers (Davies, 2004), native speakers refer to people who acquired a language from birth and know the language intuitively (Davies, 1991; Paikeday, 1985; Phillipson, 1992; Stern, 1983). Besides that, there are certain characteristics such as dominance, comfort of use, self-perception of linguistic identity, having comprehensive idiomatic forms of language, and able to produce spontaneous discourse which can be attributed to native speakers (Davies, 2004; Nayar, 1994).

Thus, native speakers seem to have more advantages than non-native speakers, leading the former ones to be preferred as the ideal model of language as well as language teachers (Jenkins, 2000; Phillipson, 1992). Furthermore, language proficiency is often associated with teaching competence (Seidholfer, 1999). Walkinshaw and Duong (2012) study on NEST and NNEST in Vietnam indicated the preferences of students in Vietnam over NEST whom were regarded as more fluent and possessing high level of subject knowledge. In addition, Cheng (2009) reported that a group of Taiwanese elementary school students preferred to have NEST due to their American accent. Lasagabaster and Sierra (2005) also highlighted students' preference over NEST because of their pronunciation and cultural knowledge. It can be said that NEST are regarded as more superior than NNEST due to their linguistic background.

Nevertheless, some studies have debated the superiority of NEST over NNEST. In this regards, despite a long-held belief of NEST's superiority over NNEST, there is no research which indicates the claim (Bueno, 2006). 'Native Speaker Fallacy' is a terminology which is dubbed by Phillipson (1992) to describe the belief of native speaker as an ideal teacher. This belief has been argued in several studies. Conducting a study on teaching success of NEST and NNEST in ten different countries, Medgyes (1994) showed that both teachers had an equal chance to be successful English teachers. Furthermore, despite an argument that claims NNEST might not achieve similar level of competence like NEST (Medgyes, 1992), language competence does not always correspond with 
the ownership of language (Rampton, 1990) and guarantee the success of teaching his or her native language (Canagarajah, 1999; Medgyes, 1994, 1999).

In addition, non-native speakers are more qualified to teach a language than those who were born to it because non-native speakers have undergone similar process of learning a language like the students (Braine, 1999; Medgyes, 1994). Besides that, students might have more concern on teachers' methodology, teaching skills than the native language of their teachers. Several research have been conducted in various countries such as Hong Kong (Cheung and Braine, 2007), the USA (Liang, 2002), Vietnam (Walkinshaw and Duong, 2012), and the United Kingdom (Pacek, 2005). Those studies revealed teachers' pedagogical background, teaching experience, teaching qualification, personal qualities (friendliness, enthusiasm), and understanding of the local culture as factors that are valued more by students than teacher's native language. It can be said that the superiority of NEST over NNEST still needs to be researched heavily and the native language of teachers might be something valued less by students than other factors.

In addition, NNEST do not always lead to less motivated students. The participants of Liu and Zhang's (2007) study were more enthusiastic to learn English with NNEST, whom they considered as more prepared than NEST. Other factors such as teachers' knowledge and class preparation might influence students' motivation and attitudes regardless of the nationality status of their teachers. Mahboob's (2003) study on students' perceptions toward NEST and NNEST indicated how the participants regarded NNEST as knowledgeable in grammar, hard workers, and have stricter methodology. Karakas et al's (2016) study on Turkish EFL learners' perceptions of NEST and NNEST in higher education indicated the positive perceptions of participants on NNEST's pedagogical dimensions. These positive perceptions might motivate students to learn English with NNEST. Thus, students do not always perceive NNEST less due to their linguistic background because students still consider other factors such as teachers' methodology or knowledge.

Despite numerous studies toward this matter, investigating students' perceptions of teachers and their effect on students' motivation might be beneficial to provide more information. In 2017, Pae conducted a study on the differences in motivation and attitudes of a group of English students in South Korea whereas Adara (2018) investigated preferences and motivation of a group of Indonesian students toward NEST and NNEST. However, a study which specifically designed to investigate the differences in students' motivation and perceptions of NEST and NNEST in the context of ESL learners Indonesia has not been conducted yet. As mentioned by Beath (2010), it is important to examine motivation of different types of learners as different research objects might lead to different results. Investigating students' motivation of English learners in Indonesia might provide researchers and educators with different results than ones provided by researchers who focused on students on different countries. It is why the present study is important to be conducted as it might fill the gap of knowledge in the differences on Indonesian students' motivation and attitudes toward NEST and NNEST. In addition, the present study aims to investigate factors which lead to the differences on students' motivation and attitudes. 


\section{METHOD}

The present study applied a mixed-method approach to investigate the matter. There are two research instruments used in the present study; a set of questionnaires and interviews. The questionnaires were adapted from Deci and Ryan's (1985) Self Determination Theory. The questionnaire was used because SDT is argued to be better at explaining students' motivation (Dörnyei, 1990). In addition, the questionnaires use a Likert scale and apply following four responseoptions: strongly disagree, disagree, agree, and strongly agree.

There are twenty items in the questionnaire. They were designed to gather information toward the participants' motivation in learning English with NEST and NNEST. On the other hand, the participants are sixty junior high school students in a private school in Bekasi, Indonesia. The participants were chosen because they had been taught by both NEST and NNEST for more than two years. They attend twice a week English lessons with NNEST for two hours as well as a weekly English session with NEST. A session with a NEST is always accompanied with a translator. Both NEST and NNEST that taught them were qualified English teachers.

However, whereas NNEST are permanent teachers in that school, NEST are hired by an English teaching agency which specializes in providing teachers to companies, schools or private courses. The age range of participants is 14 to 15 year old. Due to the nature of present research, obtained data will be analyzed differently. In this regard, quantitative data is analyzed using SPSS whereas qualitative data is transcribed and coded according to several categories; students' motivation to English learning, students' motivation and perceptions of NEST and NNEST.

\section{RESULTS AND DISCUSSION}

Following table displays students' motivation and perceptions of NEST. These findings will be compared with students' motivation and perceptions of NNEST. The interviews' results will be used to support the quantitative data. Factors which influence the differences in students' motivation and perceptions of NEST and NNEST will be implied from both qualitative and quantitative findings.

Table 1: Students' Motivation and Perceptions of NEST

\begin{tabular}{|c|l|c|c|r|}
\hline No & \multicolumn{1}{|c|}{ Items } & Mean & Median & $\begin{array}{c}\text { Std. } \\
\text { Deviation }\end{array}$ \\
\hline 1 & $\begin{array}{l}\text { I want to speak as fluent as my native } \\
\text { English speaking teachers. }\end{array}$ & 3.3333 & 3.0000 & .60132 \\
\hline 2 & $\begin{array}{l}\text { Native English speaking teachers have } \\
\text { better accents than non-native teachers. }\end{array}$ & 3.1167 & 3.0000 & .69115 \\
\hline 3 & $\begin{array}{l}\text { I enjoy listening to English spoken by } \\
\text { native speakers. }\end{array}$ & 3.1333 & 3.0000 & .76947 \\
\hline 4 & $\begin{array}{l}\text { Native English speaking teachers motivate } \\
\text { me to learn grammar. }\end{array}$ & 3.0667 & 3.0000 & .73338 \\
\hline 5 & $\begin{array}{l}\text { I like learning about American or British } \\
\text { cultures from native speakers. }\end{array}$ & 2.9500 & 3.0000 & .67460 \\
\hline 6 & $\begin{array}{l}\text { Learning English with native teachers is } \\
\text { more interesting than non-native teachers. }\end{array}$ & 2.9333 & 3.0000 & .79972 \\
\hline
\end{tabular}




\begin{tabular}{|c|l|c|c|c|}
7 & $\begin{array}{l}\text { Native English speaking teachers motivate } \\
\text { me to speak English more in the } \\
\text { classroom. }\end{array}$ & 2.9167 & 3.0000 & .69603 \\
\hline 8 & $\begin{array}{l}\text { I feel more excited to study English with } \\
\text { native teachers. }\end{array}$ & 2.9167 & 3.0000 & .69603 \\
\hline 9 & $\begin{array}{l}\text { If I want to travel abroad, I have to } \\
\text { practice speaking with native teachers. }\end{array}$ & 2.8167 & 3.0000 & .77002 \\
\hline 10 & $\begin{array}{l}\text { My speaking, listening, reading and } \\
\text { writing skills of English are improved after } \\
\text { being taught by native English speaking } \\
\text { teachers. }\end{array}$ & 2.7000 & 3.0000 & .78762 \\
\hline
\end{tabular}

\section{Students perceive learning with NEST will improve their speaking skills}

The above table shows that the most salient factor that affects students' motivation to learn English with NEST is their wish to be more fluent in English. Similar to the above results, some studies also indicated students' perceptions of NEST as adept in improving students' oral skills (Madrid and Cañado, 2004; Walkinshaw and Oanh, 2014). In her study on the advantages and disadvantages of NEST and NNEST in Hong Kong, Ma (2012) argued that NEST created an authentic English-speaking environment due to their inability to speak in students' L1 to the point students were 'forced' to use English. This might lead to students' perceptions of effective and efficient learning of English because they can practice English with NEST without resorting to students' L1. In addition, students might choose native speakers as teachers because students regard NEST as perfect or authentic models as language (Braine, 1999) or the dependable source of language input who offers the standard language model to students (Mahboob, 2010). Following statement is mentioned by Student D about her motivation to learn English with NEST:

"Well, you know like they speak, and then when we go home, we can search it in Google so we know the meaning and we, they like, teach us, is more like English more than local teachers. Cause, cause, I don't know, they're from New York, they're from London so they know the word, they know the culture, I don't know."

Despite the above points, it is interesting to note that the least salient factor shown in Table 1 is students' perception of lack of improvement in English skills after being taught by NEST. It can be said that despite their wish to be more fluent after being taught by NEST, students think that being taught by NEST does not correspond with an increase in their English skills. A study of Al-Noursi (2013) on the effects of NEST and NNEST on students' achievements in speaking skills suggests that teachers' linguistic background has no significant differences on students' speaking scores. In this sense, being taught by NEST might not always lead to the improvement in English skills. However, students' lack of improvement in English skills can be influenced by other variables such as time students spent with NEST and to improve their English skills, family's support, and interest in English. Therefore, NEST might be not the only factor which affects students' lack of improvement in English. Nevertheless, NEST can still 
help creating a conducive learning experience to students as NEST provide students with an effective English learning experience.

\section{Students are motivated to learn English with NEST because of their accents and cultural knowledge}

In addition, Table 1 shows that students' enjoy listening to NEST and think that NEST have better accents than NNEST. The participants of Ma's (2012) study think the advantage of being taught by NEST is a chance to be exposed them to different accents of English. Following comment also shows students' perceptions of NEST' accents

"Umm, I think. No, wait. I think the...the native speakers are actually more, more... They have a lot of knowledge...Starting from their accent. Their...style of...teaching. And? Yeah, I guess that's it. Native speakers (are better) I guess." Student C

"[NEST] speak English, very, very great, like, it's very easy to... speak it but...hard to learn it." Student D

The above comments imply students' preferences of NEST due to their accents and teaching styles. Kelch and Williamson's (2002) study on ESL students' attitudes on native and non-native speaking instructor's accent indicated students' more critical attitudes to instructors with non-standard varieties of English' accent. Nevertheless, the participants of Kelch and Williamson (2002) could not accurately guess teacher' linguistic background from their accents only. Similar results were also found in a study of Chiba et al (1998) which investigated Japanese university students' ability to recognize spoken English from nine countries. Only small numbers of participants could correctly guess which recording belong to native speakers.

These studies imply students' preferences to NEST' accents might be influenced by their preconception that NEST' accents are better than NNEST. Kelch and Williamson's (2002) study revealed students' perceptions of native speaker' accents to favorable traits such as high level of education, better teaching experience, and excellent performance in teaching. However, a study of Alghofaili and Elyas (2017) showed that in lieu to the nativity of teachers' accents, students' are more concerned on whether the accents are understandable or not. Thus, students might prefer NEST' accents because students think NEST' accents are more understandable than NNEST. In addition, students might think having accents like native speakers make them better speakers of English.

Table 1 also shows that NEST motivate students to learn grammar and culture from English speaking countries. This point is also reflected in following comment from Student D, "They teach speaking and grammar better. Honestly, native speaker is teaching in, umm, speak and grammar is better like, the best. Umm, better than the local teacher." On the other hand, several studies show that students perceive grammar teaching as the one of weaknesses of NEST (Lasagabaster and Sierra, 2005; Ma, 2012; Walkinshaw and Oanh, 2014). Thus, it takes a specific study on the effects of NEST on students' improvement in grammar skills to corroborate the results of present study. Regarding students' perceptions of NEST and cultural teaching, several studies also report students' 
preferences over NEST because students think they are more capable to teach cultures of native English speaking countries (Adara, 2018; Arva and Medgyes, 2000; Mahboob, 2004; Lasagabaster and Sierra, 2005). In addition, Table 1 shows that students think NEST motivate them to speak and study English.

Similar to the above results, Luk's (2001) study in Hong Kong showed that students perceived NEST as valuable assets in enriching their linguistic resources and personal experiences. Lasagabaster and Sierra's (2005) also indicated NEST' roles in motivating students to speak English more in the classroom. Besides that, it can be seen from Table 2 that students perceive learning English with NEST will prepare students when they travel abroad. Thus, the above findings imply several points; students were motivated to learn English with NEST because students think it will improve their speaking skills, students' preferences of NEST' accents, and students' interests in listening to NEST. These findings will be compared with students' perceptions of NNEST and their motivation to learn English with NNEST.

Table 2: Students' Motivation and Perceptions of NNEST

\begin{tabular}{|c|l|c|c|c|}
\hline No & \multicolumn{1}{|c|}{ Items } & Mean & $\begin{array}{c}\text { Media } \\
\mathrm{n}\end{array}$ & $\begin{array}{c}\text { Std. } \\
\text { Deviatio } \\
\mathrm{n}\end{array}$ \\
\hline 21 & $\begin{array}{l}\text { Non-native English speaking teachers } \\
\text { understand how hard it is to learn English. }\end{array}$ & 3.1333 & 3.0000 & .70028 \\
\hline 22 & $\begin{array}{l}\text { Non-native English speaking teachers } \\
\text { motivate me to learn English. }\end{array}$ & 2.9500 & 3.0000 & .83209 \\
\hline 23 & $\begin{array}{l}\text { I study English better with non-native } \\
\text { English speaking teachers. }\end{array}$ & 2.9500 & 3.0000 & .59447 \\
\hline 24 & $\begin{array}{l}\text { Non-native teachers give more activities } \\
\text { that make me understand English. }\end{array}$ & 2.9167 & 3.0000 & .71997 \\
\hline 25 & $\begin{array}{l}\text { Non-native teachers can explain difficult } \\
\text { lessons easily. }\end{array}$ & 2.7833 & 3.0000 & .84556 \\
\hline 26 & $\begin{array}{l}\text { If I don't understand something, I can ask } \\
\text { in Bahasa Indonesia. }\end{array}$ & 2.7667 & 3.0000 & .78905 \\
\hline 27 & $\begin{array}{l}\text { Non-native teachers understand what I said } \\
\text { both in English and Bahasa Indonesia. }\end{array}$ & 2.7667 & 3.0000 & .78905 \\
\hline 28 & $\begin{array}{l}\text { I like listening to English spoken by non- } \\
\text { native English speaking teachers. }\end{array}$ & 2.6667 & 3.0000 & .79547 \\
\hline 29 & $\begin{array}{l}\text { I feel more relaxed to study English with } \\
\text { non-native than native teachers. }\end{array}$ & 2.6167 & 3.0000 & .69115 \\
\hline 30 & $\begin{array}{l}\text { Non-native English speaking teachers give } \\
\text { me cultural knowledge like native teachers. }\end{array}$ & 2.3833 & 2.0000 & .73857 \\
\hline
\end{tabular}

\section{Students are motivated to learn English with NNEST because they understand students' difficulties in learning English}

It can be seen from Table 2 that NNEST' understanding of students' difficulties to learn English, NNEST' motivation to students, and students' perceptions of better learning experience with NNEST as the most salient factors which affect students' motivation to learn English with NNEST. Few studies 
suggest students' preferences on NNEST due to teachers' understanding of students' difficulties on English learning (Arva and Medgyes, 2000; Pae, 2017; Walkinshaw and Oanh, 2014). Following comment from Student D shows NNEST' effect on students' motivation to learn English, "[NNEST] always tells us about, story, how, he learn English. Like, he motivate me to...learn English more so I can go college to London."

Students might be more motivated to learn English with NNEST because they see successful examples of EFL learners in NNEST (Cook, 2005; Lee, 2000). A comment from Student B suggests students' perceptions of NNEST, "Umm...I think, from the long time ago, a, the first person is local teacher that motivates me to study English." These perceptions can be attributed to the fact that students and NNEST share similar L1 and experience of learning a foreign language. Thus, NNEST might have better insights on what students need (Ma, 2012; Samimy and Brutt-Griffler, 1999) and are more empathetic to students' needs as well as problems (Arva and Medgyes, 2000; Medgyes, 1994). Similar result was also indicated in several studies (Lipovsky and Mahboob, 2010; Ma, 2009; Mahboob, 2003). The above results indicate positive traits of NNEST perceived by students.

However, this trait of NNEST can have both good and bad effects. Although NNEST can guess what students need from their own learning experience, it may make NNEST less eager in asking students really want. When asked about which teachers motivated them the most, Student C and D thought NEST provide them with more motivating games and activities than NNEST. Furthermore, Student D thought NNEST should find more motivating activities.

"Well, from native, I expect him to learn more Bahasa so he can tell us the meaning, the word in Bahasa too so we can really understand it, and from local teacher, please, please, this is my request and other friend' request, let us watch film or game, and not just, I mean they teach us with game..." Student D

Several studies also reported students' perceptions of NEST as more creative than NNEST because of variety of interesting activities as well as materials provided by NEST (Arva and Medgyes, 2000; Law, 1999; Ma, 2012). Those studies reported the penchants of NEST for taking materials from various sources such as newspapers or advertisements. Nevertheless, as shown by the next salient factors, students were still motivated to learn English with NNEST because NNEST provide students with motivating activities as well as NNEST' abilities to explain difficult lessons easily. Following comment suggest what kind activities that students find interesting from NNEST.

"[NNEST are] not as good as the natives but, local teachers actually teach us what is on the test. Like daily test or something. [NNEST] are pretty much little bit more serious, like they give you exercises and they give you a lot of formulas. No, not a lot. Sometimes, they give you homework.” Student C

The above comment indicated test preparation and grammar teaching as aspects that make students motivated to learn English with NNEST. In addition to test preparation and grammar teaching, NNEST have been reported to be more prepared than NEST in terms of teaching materials (Benke and Medgyes, 2005; 
Ma, 2012; Medgyes, 2001). On the other hand, NEST were criticised because of their lack of test preparations (Johnson and Tang, 1993). As argued by Cheng and Dörnyei (2007), people tend to spend their time to do things they find stimulating. In this regard, teachers need to know their students' interest because it will have positive impacts on learning process (Mayer, 1998; Hardre et al, 2008). Therefore, to cater students' needs, it seems important for NNEST to adopt NEST' flexibility in creating teaching materials as well as taking input from students while maintaining their expertise in test preparations. In addition, related to the two least salient factors shown on Table 4; students' relaxed feeling while studying English with NNEST and cultural knowledge taught by NNEST, NNEST might take more relaxed atmosphere to language classrooms as well as integrating cultural knowledge to lessons.

Students are motivated to learn English with NNEST because students can
resort to L1 when they do not understand some 'difficult' concepts in English

Table 2 also indicates students' preferences to NNEST because students can resort to their mutual L1 when needed. Following comments comprise students' perceptions of NNEST resorting to L1:

"Yes, they understand Bahasa Indonesia and they understand the students." Student A

“Umm, local. Because I really don't know all the vocabularies that other, that the natives say so I like more understand local once because they can also speak Bahasa (Indonesia). If I don't understand what they're saying, they can just say it again in Bahasa (Indonesia)." Student C

"To be honest [I feel more comfortable with] local teacher because, native teachers can't speak in Bahasa (Indonesia). Sometimes, so, so they, they don't know the word so when we want to speak English but, but don't know the word so we ask them to help us but they don't know the word, too so...it's kinda hard." Student D

Although the use of L1 in EFL settings is still debated (Bhooth et al, 2014), some studies have shown the advantages of NNEST because they can explain meta language concepts such as grammar in shared L1 (Cheung and Braine, 2007; Ma, 2009; Medgyes, 1994). Despite the arguments that the use of L1 in EFL classrooms can minimize L2 inputs and halt the progress (Bouangeune, 2009; Ellis, 1985; Auerbach, 1993), several studies argue that the use of L1 can lead to more effective learning, especially for beginner and intermediate classes (Sharma, 2006; Storch and Wigglesworth, 2003; Al-Nofaie, 2010; Salah and Farrah, 2012; Tang, 2002; Swain and Lapkin, 2000). However, the use of L1 should be conducted in appropriate times and manners (Atkinson, 1993; Jadallah and Hasan, 2011). For example, Meyer (2008) noted that classroom management can be conducted better in L1 before translated to L2.

On the other hand, Bhooth et al (2014) suggest the use of L1 for pedagogical strategies in order to maximize learning and students' engagement. However, both studies stressed the importance of balance in giving L1 to minimize students' dependence of L1. Therefore, the use of L1 can have positive 
impacts on EFL settings as long as the use is still minimized to urgent contexts such as explaining 'difficult' grammar items or vocabulary. In this sense, NNEST should know appropriate times to use L1, not just because students think it is more convenient for them. In addition, learning students' L1 can be beneficial for NEST. Besides closing the gap between students and NEST, Schweers (1999) argued that students can identify themselves with NEST better as well as showing respects to students' L1. The above points suggest the benefits of appropriate usage of L1 in FL classrooms by both NEST and NNEST.

Based on the above results and discussions, students have their own perceptions of NEST' and NNEST' advantages as well as disadvantages. To minimize the disadvantages, 'co-teaching' seems imperative to increase the teaching quality and students' learning outcomes (Braine, 1999). In addition, preservice teachers, both NEST and NNEST, should be aware of their advantages and disadvantages so that they can reduce their disadvantages. To help the matter, educational institutions should provide their NEST and NNEST teachers with inservice trainings about collaborations between both teachers.

\section{CONCLUSION}

The present study analyzed the differences in students' motivation and perceptions of NEST and NNEST. A mixed-method approach was applied to obtain the results. A set of questionnaires was distributed to sixty junior high school students in Bekasi while interviews were conducted to four of them. The results indicate following items as factors which influence students' motivation and perceptions of NEST and NNEST:

\section{Students perceive learning with NEST will improve their speaking skills}

The above perception can be caused by several factors. Besides creating authentic English speaking environment as mentioned in the previous paragraph, students might believe that only native speakers can be ideal teachers. Thus, students were more motivated to study English with NEST because they think it will allow them chances to practice English with ideal language models, resulting in oral fluency. However, the above results also suggest that students do not think their speaking skills improved after being taught by NEST. Although there should be a test on the effects of NEST on students' speaking skills to verify students' perceptions, these perceptions of low improvement in oral skills might be caused by several factors such as students' interests in English, family, peers, and time spent with NEST as well as improving their English skills. To corroborate the results of present study, there should be a specific study on the effects of NEST on students speaking skills. This study should be a long term one in order to measure students' speaking achievements from time to time.

\section{Students are motivated to learn English with NEST because of their accents and cultural knowledge}

Students seem to find the accents of NEST as more interesting than NNEST. These perceptions might be influenced by their preconceptions of the accents of NEST as the signs of higher education level as well as longer experienced in teaching. However, several studies show that students mostly fail to identify the linguistic background of teachers from their recording only. These preferences can 
be attributed to students' perceptions of NEST's accents as more intelligible than NNEST's. However, the aforementioned suggestion needs to be supported in a further study on Indonesian students' motivation and attitudes to the accents of NEST and NNEST. In addition, there should be a study on the effects of teachers' accents on students' motivation. In addition, such study will analyze factors that influence students' perceptions of the accents of NEST and NNEST.

\section{Students are motivated to learn English with NNEST because they understand students' difficulties in learning English}

Due to shared experience of learning L2, NNEST are perceived as more empathetic to students' learning difficulties. It might help NNEST anticipating students' needs, even before they are addressed by students. However, it can make NNEST less eager in asking what their students really want for their language classrooms. To accommodate students' needs, it seems imperative for NNEST to find more interesting materials besides text books required by schools or language institutions. A study which specifically investigates students' motivation and attitudes on NEST and NNEST' teaching materials seems imperative to be conducted because it will provide more insights on this matter.

\section{Students are motivated to learn English with NNEST because students can resort to L1 when they do not understand some concepts in English}

Resorting to L1 to explain meta-language concepts seems helpful for students. In spite of the arguments that using L1 can impede language learning' progress, several studies suggest the benefits of using L1 in moderation and appropriate times. In addition, learning students' L1 can help NEST to build a better rapport with their students. A study that specifically examines Indonesian students' perceptions of the use of L1 in language classrooms can be a good start. Furthermore, the effects of NEST and NNEST' use of students' L1 seem to be important to be investigated to shed more information on this matter.

Despite the efforts to minimize them, the present study is not without limitations. Firstly, this study, despite applying a mixed-method approach as data collecting techniques, can still benefit from more research instruments such as classroom observation or teachers' and students' journals. Classroom observation can give researchers deeper insights on students' reactions and classroom performance while being taught by NEST or NNEST. On the other hand, journals can provide researchers with students' or teachers' feedback as well as opinions about NEST or NNEST. Further study can also obtain deeper and better information if it is performed in longer period. In addition, a bigger numbers of participants might help researchers to obtain better representation of the population. A clear number of learners who have been taught by both NEST and NNEST can provide researchers with better sampling techniques.

\section{REFERENCES}

Adara, R. A (2018) Students' Motivation and Preferences toward Native and NonNative English Speaking Teachers. Premise Journal, pp. 121. http://dx.doi.org/10.24127/pj.v7i1.1329 
Al Noursi, O. (2013). The Effect of Native and Nonnative English Language Teachers on Secondary Students' Achievement in Speaking Skills. Jordan Journal of Educational Sciences. 9, pp. 243-254.

Albakrawi, H. (2014). Is there a difference between native and non-native English teachers in teaching English? Journal of Scientific Research and Studies. $1(6)$, pp. 87-94.

Alghofaili, N. M., and Elyas, T. (2017). Decoding the Myths of the Native and Non-Native English Speakers Teachers (NESTs \& NNESTs) on Saudi EFL Tertiary Students. English Language Teaching, 10(6), pp.1-11. http://dx.doi.org/10.1016/j.cedpsych.2010.08.001

Al-Nofaie, H. (2010). The attitudes of teachers and students towards using Arabic in EFL classrooms in Saudi public schools. Novitas-ROYAL (Research on Youth and Language) 4(1), pp. 64-95.

Arva, V., and Medgyes, P. (2000). Native and non-native teachers in the classroom. System, 28, pp. 355-372.

Aslan, E. and Thompson, A. S. (2016) Native and non-native speaker teachers: contextualizing perceived differences in the Turkish EFL setting. LIF Language in Focus Journal, 2 (1). pp. 87-102.

Atkinson, D. (1993). Teaching monolingual classes. London: Longman.

Auerbach, E. R. (1993). Re-examining English only in the ESL classroom, TESOL Quarterly, 27(1), pp. 9-32.

Beath, O. (2010) "I Want to be More Perfect than Others": a Case of ESL Motivation, Paper presented at the Faculty of Education and IERI HDR Conference, University of Wollongong, 12 November 2010.

Benke, E., and Medgyes, P. (2005). Differences in teaching behaviour between native and nonnative speaker teachers: As seen by the learners. In E. Llurda (Ed.), Nonnative language teach teachers: Perceptions, challenges and contributions to the profession (pp. 195-215). New York, NY: Springer.

Bhooth, A., Azman, H., and Ismail, K. (2014). The role of the L1 as a scaffolding tool in the EFL reading classroom. Procedia - Social and Behavioral Sciences 118, pp.76-84.

Boecher, Y. (2005) Native and Non-native English-Speaking Teacher Distinctions: From Dichotomy to Collaboration, The CATESOL Journal, pp.67-75.

Bouangeune, S. (2009). Using L1 in teaching vocabulary to low English proficiency level students: A case study at the University of Laos. English Language Teaching Journal 2(3), pp. 186-193.

Braine, G. (Ed.). (1999) Non-native educators in English language teaching. Mahwah: Lawrence Erlbaum.

Bueno, C. (2006). Native English teacher required. TESL-EJ,

Canagarajah, A. S. (1999). Interrogating the "native speaker fallacy": Nonlinguistic roots, non-pedagogical results. In G. Braine (Ed.), Non-native educators in English language teaching (pp. 77-92). Mahwah, NJ: Erlbaum.

Carrió-Pastor, M.L. and Mestre, E. (2014). Motivation in Second Language Acquisition. Procedia Social and Behavioral Sciences 116, pp.240-244. 
Cheng, H and Dörnyei, Z (2007) The Use of Motivational Strategies in Language Instruction: The Case of EFL Teaching in Taiwan, Innovation in Language Learning and Teaching, 1:1, pp.153-174.

Cheung, Y. L., and Braine, G. (2007). The attitudes of university students towards non-native speaker English teachers in Hong Kong. RELC Journal, 38, pp. 257-277.

Chiba, R., Matsuura, H., and Yamamoto, A. (1995). Japanese attitudes towards English accents. World Englishes, 14, pp. 77-86.

Cook, V. (2005). Basing teaching on the L2 user. In E. Llurda (Ed.), Nonnative language teachers: Perceptions, challenges and contributions to the profession (pp. 47-61). New York: Springer.

Davies, A. (1991). The native speaker in applied linguistics. Edinburgh University Press.

Davies, A. (2004). The native speaker in Applied Linguistics. In A. Davies and C. Elder (Eds.), The Handbook of Applied Linguistics, (pp. 431-450). Oxford: Blackwell.

Deci, E. L., and Ryan, R. M. (1985). Intrinsic motivation and self-determination in human behavior. New York: Plenum.

Dörnyei and Ottó, I. (1998). Motivation in action: A process model of L2 motivation. Working Papers in Applied Linguistics (Thames Valley University, London), 4, pp. 43-69.

Dörnyei, Z (1998). Motivation in second and foreign language learning. Language Teaching, 31, pp. 117-135

Dörnyei, Z. (1990). Conceptualizing motivation in foreign language learning. Language Learning, 40, pp. 46-78.

Dörnyei, Z. (2001) Teaching and Researching Motivation. Harlow: Longman.

Dornyei, Z. (2005). The Psychology of the Language Learner: Individual Differences in Second Language Acquisition. Mahwah: Lawrence Erlbaum Associates.

Dörnyei, Z., and K. Csizer. (1998). "Ten Commandments for Motivating Language Learners: Results of an Empirical Study.' Language Teaching Research 2 (3), pp.203-229.

Ellis, R (1994). The study of second language acquisition. Oxford: Oxford University Press.

Ellis, R. (1985). Understanding second language acquisition. USA: Oxford University Press.

Gardner, R. C. (1985). Social Psychology and Second Language Learning: The Role of Attitudes and Motivation. London: Edward Arnold.

Gardner, R.C. (2005) Integrative motivation and second language acquisition. (Joint Plenary Talk), Canadian Association of Applied Linguistics/Canadian Linguistics Association.

Hardre', P. L., D. W. Sullivan, and N. Roberts. (2008). Rural High School Teachers' Best Motivating Practices. The Rural Educator 30 (1), pp.19-31. 
Harmer, J. (1991). The Practice of English Language Teaching, London: Longman.

Huang, C. (2007). Why Do University Students want to learn English? Master Thesis, Providence University.

Jadallah, M. and Hasan, F. (2011). A review of some new trends in using L1 in the EFL classroom. www.qou.edu/english/conferences/firstNationalConference/.../drMufeed.pdf. 12 June 2013

Jenkins, J. (2000). The phonology of English as an international language. Oxford: Oxford University Press.

Karakaş, A., Uysal, H., Bilgin, S., and Bulut, B. (2016). Turkish EFL learners' perceptions of native English speaking teachers and non-native Englishspeaking teachers in higher education. Novitas-ROYAL (Research on Youth and Language), 10(2), pp. 180-206.

Kelch, K., and Santana-Williamson, E. (2002). ESL students' attitudes toward native- and non-native-speaking instructors' accents. CATESOL Journal, 14 (1), pp.57-72.

Lagabaster, D and Sierra, J.M. (2005) The Nativeness Factor: An Analysis of Students' Preferences. ITL - International Journal of Applied Linguistics 147/148, pp. 21-43.

Lamb, M.V. (2007). The motivation of junior high school pupils to learn English in provincial Indonesia. $\mathrm{PhD}$ Thesis. University of Leeds.

Lasagabaster, D., and Sierra, J. M. (2005). What do students think about the pros and cons of having a native-speaker teacher? In E. Llurda (Ed.), Nonnative language teachers: Perceptions, challenges and contributions to the profession (pp. 217-242). New York: Springer.

Law, W. K. (1999). Students' perception of the NET (native English speaking teacher) in motivating students to learn English: A case study in a band 5 school (Unpublished master's thesis). University of Hong Kong: Hong Kong.

Lee, I. (2000). Can a non-native English speaker be a good English teacher? TESOL Matters, 10(1), pp. 19.

Liang, K. (2002). English as a second language students' attitudes toward nonnative English-speaking teachers' accentedness (Unpublished master's thesis) California State University, Los Angeles, CA.

Lipovsky, C., and Mahboob, A. (2010). Appraisal of native and non-native English speaking teachers. In A. Mahboob (Ed.), The NNEST lens: Nonnative English speakers in TESOL (pp. 154-179). England: Cambridge Scholars.

Liu, M., and Zhang, L. (2007). Student perceptions of native and non-native English teachers' attitudes, teaching skills assessment and performance. Asian EFL Journal, 9(4), pp.157-166.

Loewen, S. and Reinders, H. (2011). Key Concepts in Second Language Acquisition. Basingstoke: Palgrave Macmillan. 
Luk, C. M. (2001). Exploring the sociocultural implications of the native Englishspeaker teacher scheme in Hong Kong through the eyes of the students. Asia-Pacific Journal of Language in Education, 4(2), pp.19-50.

Ma, L. P. F. (2009). Student perceptions of native English teachers and local English teachers. In A. Mahboob and C. Lipovsky (Eds.), Studies in applied linguistics and language learning (pp. 325-348). Newcastle upon Tyne: Cambridge Scholars.

Ma, L. P. F. (2012). Advantages and disadvantages of native- and nonnativeEnglish- speaking-teachers: Student perceptions in Hong Kong. TESOL Quarterly, 46 (2), pp. 280-305.

Madrid, D and Cañado, M (2004) Teacher and Student Preferences of Native and Nonnative Foreign Language Teachers. PORTA LINGUARUM 2, pp.124138.

Mahboob, A. (2003). Status of nonnative English-speaking teachers in the United States (Unpublished doctoral dissertation). Indiana University: Bloomington.

Mahboob, A. (2004). Native or Non-Native: What do the Students Think. In L. D. Kamhi-Stern (Ed.), Learning and Teaching from Experience (pp. 121-147). Michigan: University of Michigan Press.

Mahboob, A. (2010). The NNEST lens. In A. Mahboob, (Ed.), The NNEST Lens: Non Native English Speakers in TESOL, (pp. 1-17). Newcastle upon Tyne: Cambridge Scholars Publishing.

Mayer, R. E. (1998). Cognitive, Metacognitive, and Motivational Aspects of Problem Solving. Instructional Science 26 (1/2), pp. 49-63.

McDonough, S. (1983). Psychology in foreign language learning. George, Allen and Unwin: London.

Medgyes, P. (1992). Native or non- native: Who's worth more? ELT Journal, 46 (4), pp. 340- 349.

Medgyes, P. (1994). The non-native teacher. England: Macmillan.

Medgyes, P. (2001). When the teacher is a non-native speaker. In M. CelceMurcia (Ed.), Teaching English as a second or foreign language, Third edition (pp. 415-428). Boston: Heinle \& Heinle.

Mesbah, Z and Khazaie, Z. (2014). The Relationship between Extrinsic vs. Intrinsic Motivation and Strategic Use of Language of Iranian Intermediate EFL Learners. Theory and Practice in Language Studies. 4, pp. 99-109. 10.4304/tpls.4.1.99-109.

Meyer, H. (2008). The pedagogical implications of L1 use in the L2 classroom. Maebashi Kyoai Gakuen College Ronsyu 8, pp. 147-159.

Oxford, R., and Shearin, J. (1994). Language learning motivation: Expanding the theoretical framework. The Modern Language Journal, 78, pp.12-28.

Pacek, D. (2005). "Personality not nationality": Foreign students' perceptions of a non-native speaker lecturer of English at a British university. In E. Llurda (Ed.), Nonnative language teachers: Perceptions, challenges and contributions to the profession (pp. 243-261). New York: Springer. 
Pae, T (2017) Effects of the differences between native and non-native Englishspeaking teachers on students' attitudes and motivation toward learning English, Asia Pacific Journal of Education, 37 (2), pp.163-178.

Paikeday, T. M. (1985). May I kill the native speaker? TESOL Quarterly, 19, pp.390-395.

Phillipson, R. (1992). Linguistic Imperialism. Oxford: Oxford University Press.

Poornima, B, et al., (2016) Factors Influencing Second Language Learning Among Urban European Language Learners: A Qualitative Study. The International Journal of Indian Psychology, 3 (7), pp. 43- 51.

Rampton, B. (1990). Displacing the native speakers: Expertise, affiliation and inheritance. ELT Journal, 44(2), pp. 97-100.

Salah, N. M. H. and Farrah, M. A. H. (2012). Examining the Use of Arabic in English Classes at the Primary Stage in Hebron Government School: Palestine: Teacher's Perspective, Arab World English Journal 3(2), pp. 400436.

Samimy, R., and Brutt-Griffler, J. (1999). To be a native or nonnative speaker: Perceptions of "nonnative" students in a graduate TESOL program. In G. Braine (Ed.), Nonnative educators in English language teaching (pp. 127144). Mahwah, NJ: Lawrence Erlbaum.

Schweers, W. (1999). Using L1 in the L2 classroom. English Teaching Forum 37(2), pp. 6-13.

Sharma, B. K. (2006). Mother tongue use in English classroom. Journal of NELTA 11(1), pp. 80-87.

Stern, H.H. (1983). Fundamental Concepts of Language Teaching. Oxford: OUP.

Storch, N. and Wigglesworth, G. (2003). Is there a role for the use of the L1 in an L2 setting? TESOL Quarterly 37(4), pp.760-769.

Swain, M. \& Lapkin, S. (2000). Task-based second language learning: The uses of the first language. Language Teaching Research 4(3), pp. 251-274.

Tang, G., and Johnson, R. K. (1993). Implementing language change in Hong Kong schools: An ecological approach to evaluation. Journal of Asian Pacific Communication, 4(1), pp. 31-47.

Tang, J. (2002). Using L1 in the English classroom. English Teaching Forum, pp. $36-43$.

Walkinshaw, I., and Duong, O. T. H. (2012). Native- and non-native speaking English teachers in Vietnam: Weighing up the benefits. TESL-EJ, 16 (3), pp. $1-17$.

Walkinshaw, I., and Oanh, D. H. (2014). Native and Non-Native English Language Teachers: Student Perceptions in Vietnam and Japan. SAGE Open, 4(2), pp.1-9.

Wu, K. and Ke, C. (2009). Haunting native speakerism? Students' perceptions toward native speaking English teachers. English Language Teaching, 2(3), pp. $44-52$ 